\section{International Scientific Journal Theoretical \& Applied Science}

\author{
p-ISSN: 2308-4944 (print) e-ISSN: 2409-0085 (online) \\ Year: $2016 \quad$ Issue: 11 Volume: 43 \\ Published: $30.11 .2016 \quad \underline{\text { http://T-Science.org }}$
}

SECTION 21. Pedagogy. Psychology. Innovations in the field of education.
Svetlana Vasilyevna Meleshko Assistant of Mathematics Department, Stavropol State Agrarian University, Russia,Stavropol meleshko-78@mail.ru

Elena Borisovna Zorina Associate Professor, Candidate of Pedagodical science, Head of Foreign languages and cross-cultural Department, Stavropol State Agrarian University, Russia,Stavropol zeb26@mail.ru

Svetlana Viktorovna Popova Senior Lecturer of Mathematics Department, Stavropol State Agrarian University, Russia,Stavropol svp0314@yandex.ru

Tatyana Aleksandrovna Gulay

Candidate of Technical Sciences, Associate Professor of Mathematics Department, Stavropol State Agrarian University, Russia,Stavropol laima5566@mail.ru

\title{
INDEPENDENT WORK AS THE MOST IMPORTANT MEANS OF RAISING PROFESSIONAL, INFORMATIVE AND CREATIVE ACTIVITY OF FUTURE SPECIALISTS
}

Abstract: In the article it is spoken about independent work as means of increasing professional-cognitive and creative activity of the future specialists, about formation of skills in independent work by means of subject-activity approach.

Key words: independent work, creative approach, information technologies.

Language: English

Citation: Meleshko SV, Zorina EB, Popova SV, Gulay TA (2016) INDEPENDENT WORK AS THE MOST IMPORTANT MEANS OF RAISING PROFESSIONAL, INFORMATIVE AND CREATIVE ACTIVITY OF FUTURE SPECIALISTS. ISJ Theoretical \& Applied Science, 11 (43): 135-138.

Soi: http://s-o-i.org/1.1/TAS-11-43-24 Doi: crossef http://dx.doi.org/10.15863/TAS.2016.11.43.24

\section{Introduction}

In recent years the requirements for the training of young specialists significantly increased. To prepare competent professional it needs to provide him such complex of knowledge and skills that would help him to successfully find a job after graduation, that is, the complex must meet certain requirements of employers to the graduates. The employer hires competitive young professionals with the following qualities:

1. Professional competence;

2. Communicative competence;

3. Positive attitude to his profession;

4. Creative approach to solving professional problems;
5. Active life position. [3]

To acquire these qualities it is very important while learning to help students in solving problems, adapting to modern conditions.

Independent work of students stands as the most important means of improving professional, cognitive and creative activity of the future specialists. It appears as the motivation of the student, his purposefulness, self-education and other qualities.

Observations of students' work at different levels of education give evidence of the insufficient level of knowledge at junior students' abilities and skills of independent work, their low willingness to research. [4] 


\begin{tabular}{|c|c|c|c|c|c|c|}
\hline Impact Factor: & $\begin{array}{l}\text { ISRA (India) } \\
\text { ISI (Dubai, UAF } \\
\text { GIF (Australia) } \\
\text { JIF }\end{array}$ & $\begin{array}{l}=1.344 \\
=0.829 \\
=0.564 \\
=1.500\end{array}$ & $\begin{array}{l}\text { SIS (USA) } \\
\text { PИНЦ (Russia) } \\
\text { ESJI (KZ) } \\
\text { SJIF (Morocco) }\end{array}$ & $\begin{array}{l}=0.912 \\
=0.234 \\
=1.042 \\
=\mathbf{2 . 0 3 1}\end{array}$ & $\begin{array}{l}\text { ICV (Poland) } \\
\text { PIF (India) } \\
\text { IBI (India) }\end{array}$ & $\begin{array}{l}=6.630 \\
=1.940 \\
=4.260\end{array}$ \\
\hline
\end{tabular}

\section{Materials and Methods}

At the same time the competence approach to training makes high demands for the level of professionalism, which in its turn leads to the need for improving the quality of classroom and students' independent work.

Analysis of the literature shows that the independent work of students:

- An activity that is carried out without the direct involvement of the teacher, but under its control;

- An activity in which the student has a desire and ability to take responsibility for managing their training activities;

- Involves an educational partnership in which both the teacher and the student are interested in;

- Is aimed not on the reproductive activity but to take student on the creative level;

- Based on the motivational sphere of learning as the basis of his personality;

- Provides organization of activities, which involves mobilizing, stimulating, developmental impact on both the entire school staff, and on each student individually [1].

The task of organization in independent work at the university associated with the solution of a number of problems related to the student preparedness for the implementation of training activities. One of the problems is the inability of students for the most part to carry out independent work. The processes of reception, interpretation, processing, and evaluation and storing information are necessary educational cause significant difficulties for students. To help solve this problem, according to the researchers, it is capable of subjectactivity approach. [2]

The basic idea of this approach is that the student is in the process of self-study shows its willingness and ability to assume responsibility for the management of its educational activity on mastering school subjects. Thus, through training, development objectives are put student's personality, the formation of the ability to manage these activities, both in the specific learning situation, and in the future in the framework of continuing education.

Subject-activity approach that focuses on the student's learning process, suggests that students are free to determine the goals and objectives of its activities, the necessary material is taken, using a variety of sources, planning the content of this activity and perform it, achieving the desired result. In this case, a certain level of independence is a necessary condition for the success of the psychological. The effectiveness of training is higher, the more the situation encourages students to free communication. Here we mean not only the students' communication with each other, but also with the teacher lectures, seminars, consultations, during school hours. [5]

Free communication implies knowledge of the studied material, possession of terminology, the ability to give examples. In lectures every student should be ready to participate in a mini-debate, to ask questions to the lecturer and to answer his questions about the lecture topic. Thus, there is the revitalization of the lectures, which are no longer exclusively monologue teacher.

Independent preparation for seminars is mandatory student performing all kinds of tasks relating to each class. The student should be ready to answer the questions according to plan lessons, firmly grasp the basic concepts and categories, to answer questions for self-examination and in writing to perform tasks relating to the problematic of each session (decision historic tasks, written answers to questions of concern, logic etc ).. Perform all tasks on the study discipline is the basis for the admission of students to the final test. This is a good incentive for self-preparation of students for the classroom training, thereby allowing to increase the efficiency of training, as well as the quality of education. [11]

A huge role in the organization of independent work plays the introduction of modern computer technology. Today, one of the characteristics of the educational environment is an opportunity for students and teachers to access structured teaching materials, teaching multimedia complex whole university at any time and at any point in space.

For example, through a section of the educational portal "My Account", the teacher puts all the necessary information to students (consultations, graphics, theory questions, tasks for independent solution, if necessary, dismantled examples and others.). $[8,10]$

As a student, preparing to engage in mathematics, for the theme "Integral calculus of functions of one variable" in the private office of the teacher will find questions for oral answer to the occupation and tasks for independent solution, which he must perform approximately as follows:

Questions on "Integral calculus of functions of one variable"

1. State the definition of a primitive function.

2. What it is called the indefinite integral of a given function?

3. List the basic properties of the indefinite integral.

4. Write a formula basic table of integrals.

5. What is called the definite integral of the function in the interval?

6. What is the geometric meaning of the definite integral?

7. List the basic properties of the definite integral.

8. Write the formula of Newton - Leibniz. 


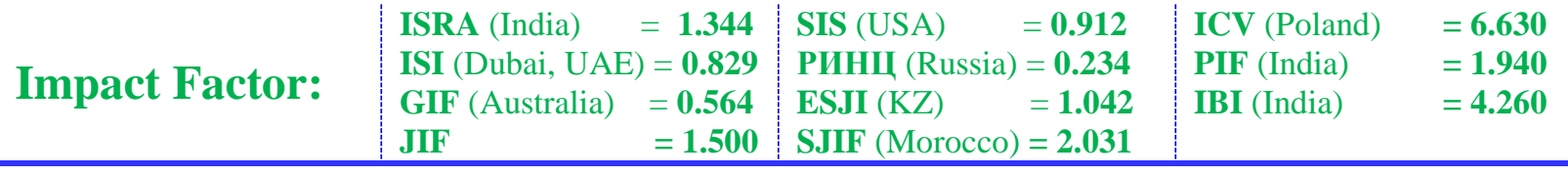

9. What is the essence of the method of integration by replacing the variable?

10. Write the formula for integration by parts in the definite and indefinite integrals.

Calculate the indefinite integral:

1) $\int 3 \sqrt{x} \ln \sqrt{x} d x$;

2) $\int \frac{20 x-2}{10 x^{2}-6 x+1} d x$;

3) $\int \cos 2 x \cdot \sin x d x$;

4) $\int \frac{x+\operatorname{arctg} x}{1+x^{2}} d x$;

5) $\int x \ln \left(x^{2}+1\right) d x$;

6) $\int(4 x-5) \cdot \sin 11 x d x$.

The service is available for any high school student. In addition to the availability of educational material, it is possible to regard him with a teacher, receiving consultation on-line or off-line mode, as well as the opportunity to receive individual advice for solving problems or prepare for the theoretical survey. $[6,12,13]$

Information technology helps the transition from reproductive learning (from the teacher to the students) to the creative model (when using logistics simulated situation or process, and the students, under the guidance of a teacher, should apply their knowledge, to be creative and come up with solutions to these problems). Experts believe that the development of traditional and new technologies should follow the principle of subsidiarity. And we fully agree with them. Computer technology should complement the communication of the teacher and the student, rather than replace it. [7, 9]

\section{Conclusion}

At the same time, students' independent work, in the era of informatization of education, information technology, take up more time and space than the direct communication student and teacher.

Using Multimedia allows students to work independently on the study material and decide how to study it, in what sequence and how to use the interactive possibilities of the software, how to implement the joint work with other members of the group and with the teacher. The computer is a tool that allows students to know better themselves; the individual characteristics of their teaching contribute to the development of independence.

Independent work is not confined to either the fact of the absence of the teacher, or even the ability to perform certain tasks without the help of a teacher. It includes a significant ability to: without any help consciously set ourselves certain goals, objectives, plan their activities and to implement it.

\section{References:}

1. Rozanova OV (2011) Ponjatie «samostojatel'naja rabota studentov» V kontekste teorii dejatel'nosti: Materialy n.-p.k. «Teoreticheskie i metodologicheskie problemy sovremennogo obrazovanija», Moscow - 2011. - 197 p.

2. Petrov AV (2000) Samostojatel'naja poznavatel'naja dejatel'nost' $\mathrm{v}$ sisteme razvivajushhego obuchenija / A.V. Petrov, L.V. Culaja, O.P. Petrova // Vestnik ChGPU. - 2000. - №4. - p. 43 - 50.

3. Gribovskaja NN (2011) Sovremennye trebovanija k podgotovke molodyh specialistov: Materialy mezhdunarodnoj n.-p.k. «Teorija i praktika sovremennoj pedagogiki». Chast' 2. Novosibirsk, 2011, - 180 p.

4. Basova NV (2011) Formirovanie uchebnoj samostojatel'nosti studentov pri obuchenii obshheprofessional'nym disciplinam: Materialy mezhdunarodnoj n.-p.k. «Teorija i praktika sovremennoj pedagogiki». Chast' 2. Novosibirsk, 2011, - 180p.
5. Meleshko SV, Popova SV (2012) Distancionnye tehnologii kak neobhodimyj komponent vneauditornoj samostojatel'noj raboty studentov pri izuchenii matematiki //Mezhdunarodnyj zhurnal social'nyh nauk. 2012. № 9-1 (25). p. $108-115$.

6. Dolgih EV, Popova SV, Smirnova NB (2008) Organizacija samostojatel'noj raboty studentovzaochnikov po matematike na baze jelektronnogo uchebno-metodicheskogo kompleksa // Jekonomika regionov Rossii: sostojanie i perspektivy razvitija: sbornik nauchnyh statej po materialam 72-j nauchnoprakticheskoj konferencii. 2008. p. 144-148.

7. Gulaj TA, Meleshko SV, Nevidomskaja IA (2013) Distancionnye tehnologii V informacionno-obrazovatel'noj srede vuza kak neobhodimoe uslovie samostojatel'noj raboty studentov pri izuchenii matematicheskih disciplin // Nauka i obrazovanie v XXI veke: sbornik nauchnyh trudov po materialam Mezhdunarodnoj nauchno-prakticheskoj konferencii: v 34 chastjah. 2013. p. 33-36. 


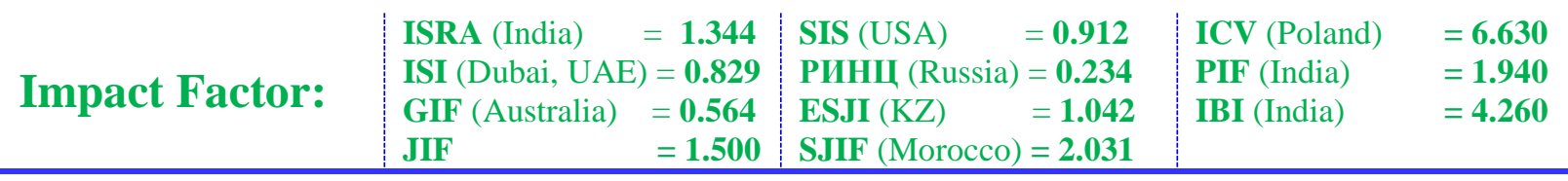

8. Zorina EB (2012) Innovacionnye tehnologii v prepodavanii inostrannogo jazyka / Modelirovanie proizvodstvennyh processov i razvitie informacionnyh sistem 2012. p. 272274

9. Gulaj TA, Meleshko SV, Nevidomskaja IA (2014) Informacionnoe obespechenie obrazovatel'noj dejatel'nosti studentov kak neobhodimaja sostavljajushhaja uspeshnoj organizacii samostojatel'noj raboty / Mezhdunarodnyj nauchno-issledovatel'skij zhurnal. 2014. № 3-4 (22). p. 35-36.

10. Zorina EB (2009) Innovacionnye tehnologii v processe obuchenija inostrannym jazykam // Sostojanie i perspektivy razvitija agropromyshlennogo kompleksa Juzhnogo Federal'nogo okruga: 73-ja nauchnoprakticheskaja konferencija. 2009. p. 284-286.

11. Titova GJ (2010) O tehnologii organizacii samostojatel'noj raboty studentov / Vestnik
Tomskogo

gosudarstvennogo pedagogicheskogo universiteta. 2010. № 1. p. 123-126.

12. Meleshko SV, Nevidomskaja IA (2012) Ispol'zovanie innovacionnyh obrazovatel'nyh tehnologij v samostojatel'noj rabote studentov pri izuchenii matematicheskih disciplin: Materialy Mezhdunarodnoj nauchnoprakticheskoj konferencii «Teoreticheskie i prikladnye problemy sovremennoj pedagogiki» - Stavropol': AGRUS Stavropol'skogo gos. Agrarnogo un-ta, 2012. p. 73 - 81.

13. Kron RV, Dolgih EV (2012) Ispol'zovanie jelektronnogo uchebno-metodicheskogo kompleksa po matematike pri organizacii samostojatel'noj raboty studenta zaochnogo obuchenija: Sbornik nauchnyh trudov Sworld po materialam mezhdunarodnoj nauchnoprakticheskoj konferencii. 2012. T. 17. № 4. p. 22-26. 